\title{
RAISING AWARENESS ON ENVIRONMENTAL PROTECTION AND IMPROVEMENT THROUGH STUDENT PROJECTS: A CASE STUDY
}

\author{
Anja BUBIK ${ }^{1}$, Lucija KOLAR ${ }^{2}$ \\ ${ }^{1}$ Environmental Protection College, 3320 Velenje, Trg mladosti 7, Slovenia \\ E-mail: anjabubik.vsvo@gmail.com \\ ${ }^{2}$ Complementarium, Institute for research of nature and development of environmental technologies, \\ 3000 Celje, Lopata 60, Slovenia
}

Paper received: 15.01.2019.; Paper accepted: 20.02.2019.

\begin{abstract}
Raising awareness on a certain topic or issue is vastly alleviated with a proliferation of the electronic media and consequently, fast information delivery. The experience shows, that this is the best and most compelling way to educate the general public. Within this paper we show how two student projects, employing various activities to raise awareness, influenced general public. We also present the benefits and negative effects of the campaigns and how they can be linked together to an interesting and educational real case scenario. Public knowledge on greening and its benefits, related to the climate changes were studied in Slovenia, with the emphasis on Savinja statistical region. We used surveys, pilot cases, organized public events and remote collaboration tools within this study. We observed lack of knowledge and experience with greening principles among general public. However, good communication skills, networking and attractive sustainable solutions have led to an increase of greening awareness. Our case study gives examples on possible approaches in the frame of climate changes prevention and is encouraging future student projects. We summarized solutions and developed appropriate tools to implement them in order to effectively and efficiently raise public awareness on sustainable integration development and greening.
\end{abstract}

Keywords: Student projects, Awareness, Greening, Survey, E-tools, Sustainable development.

\section{INTRODUCTION}

The negative effects of shrinking green spaces in the urban spaces are becoming evident, thus local and regional authorities must react and adopt environmental planning policies that can help create new green areas. These will rectify deteriorated living conditions and ensure a good quality of life for citizens, along with the rehabilitation of the natural environment. One approach is the promotion of green infrastructure on buildings, including green roofs, green walls, green gardens even through public actions, either through e-media or organization of public events. In order to effectively promote green infrastructure on buildings or greening itself, it is essential to comprehend public attitude toward green infrastructure, so that suitable and effective strategies can be implemented by policy makers. Having identified communication as the first step towards solution, we first need to reserve appropriate funding, with which we can enable appropriate public communication on this specific issue.

The urban population around the world has risen dramatically: from $13 \%$ in 1900 to up to $57 \%$ in 2017 (UN, 2017). Currently, around 7.5 billion people live on our planet and scenarios for the future show a plausible range from 8.5 to over 12 billion (Lutz, 2017; UN, 2017). According to the World Population Prospects, United Nations (2017) reports $66 \%$ of the world's population are projected to be urban residents by 2050 . Ten years ago, the global population was growing by 1.24 per cent per year. Today, it is growing by 1.10 per cent per year, yielding an additional 83 million people annually (UN, 2017). These numbers are very high, and we should start to take action how 
to preserve the nature or at least find the most adequate ways to do so (Stephenson et al., 2010). Growing population forced developers to construct more buildings and therefore, more green areas were destroyed and converted to an urban environment (Alexandria \& Jones, 2008). The rise of constructed areas without enough vegetation has changed the flow of energy and material through urban ecosystem which causes many environmental problems. First, cities tend to be hotter as the surrounding (countryside) areas and create what is known as an urban heat island. Second, urbanization affects hydrology; cities shed more water as run off to their streams and rivers. Third, cities are net producers of carbon dioxide and have lower amounts of stored carbon. Fourth, cities are widely regarded as having lower biodiversity (Whitford et al., 2001). All of these four factors affect the ecological balance of urban environment and should be carefully addressed not just locally, but also on a national scale.

Tools for assessing the human influence on the environment are increasingly available. This means we can analyze the development, knowledge and usage of various sustainable solutions and their, hopefully positive, impact on the environment. The term survey includes any studies that consist of asking individuals to respond to questions. This includes written questionnaires and personal interviews. These can be formal, informal, anonymous, internet-based, etc. However, when done well, surveys are a perfectly legitimate form of research (Panacek, 2008) and that was the reason why we used it also in one of our projects. Additional important analysis tools, used during the implementation phase of our two projects, were social media (Facebook, Twitter, LinkedIn) and open science and open data (Dushyant et al., 2014) repositories. Voytek (2017) argues that these three aforementioned tools are essential in today's communication and that Facebook and Twitter have significantly shaped the nature of social, political and scientific discourse. He says that social media can be used by scientists, whether they wish to be involved or not and explains that social media services provide unprecedented tools for scientific communication, data collection, and the study of human behavior. However, on the other hand, the abovementioned platforms can also be a very rapid responding platform of (anonymous) criticism (Voytek, 2017). Voytek (2017) supports his statements with the fact that the rapid expansion of social media occurred at the same time as the open access and reproducibility movements in science, as well as during the emergence of big data and data science. This however is not an accident, but a consequence of their inextricable interrelationship and therefore we used them also in our two cases.

Most of the above-mentioned methods were employed in our two student projects. We addressed and emphasized the potential of greening, as a possible environmental solution, aiming to increase general knowledge about it in Slovenia, mostly in Savinja statistical region. The GRACILIS (GReen Answers CLImate change) and CONVERT (CarbOn NegatiVe ExteRnal Toilet) projects transferred knowledge from Slovene academia and industry onto students, further strengthening their professional competencies. Both projects addressed the problem of climate changes through investigating effective solutions for greening of urban areas in Slovenia and greening as an added value to some sustainable products in our environment, for example ecological toilets. Within both projects the main aim was to raise public awareness on these specific issues and teaching students about best possible tools for dissemination. This paper thus shows how we gathered, managed and disseminated the knowledge in the two targeted Slovene student projects associated with greening. It also presents the benefits of raising public awareness about the mentioned topics in Slovenia, mostly in Savinja statistical region.

\section{METHODOLOGY}

The case analysis is focused on the outcomes of the two analyzed student projects performed in Slovenia and includes the following methodological principles: project communication tools, survey and its analysis, establishment of two green pilot cases and dissemination of results through public events and social media, especially Facebook. Additionally, statistical analysis was performed to gain an insight into the dissemination tools suitability and success.

Students from various Slovene universities and higher educational institutions received lessons from mentors through reading, interactive Skype conferences and face to face meetings. First, they were taught basic principles of project management and then the actual work started. They organized themselves according to their background - (e.g. computer science students worked on the internet page and economics science 
students on business models) - reports on progress using free platform (G-suite) followed and then through organization of public events they practiced public performance and sharing of knowledge.

\section{Project communication tools}

The project communication was one of the most important activities of the project groups. It enabled collaboration among all the project participants, sharing and saving the common documents and led to efficient information flow. Given these requirements, we had to find a free platform with appropriate features, and which could be easily used on different devices (mobiles, computers, tablets). We chose Google's G-Suite which has seen enormous increase in quality in the past few years and is thus now an optimized and reliable service. All this requires only internet connection and an active Google account - usually Gmail. In our project we used: Google Docs (for all work with documents and easy sharing with all participants), Google Gmail (email which is widely used also on general level), Google Scholar (enables looking for scientific and professional papers), Google Groups (enables a formation of joined email-s (e.g. project_convert@google groups.com in our case), Google Drive (cloud file storage, sharing and backup service enabling saving and sharing of documents to the group participants). These are just a few possible Google services, which are still quite unrecognized among general public. As our projects were oriented also in the sense of educating about novel approaches, we presented those possibilities whenever we had an event. We found these tools very useful as they enabled us to be highly effective, productive and efficient in the group work. We chose Google instead of Microsoft or Dropbox, as the Google's combined functionality is far superior to the aforementioned services. Additionally, some of the functionality we required would be accessible only under paid account, when using Microsoft or DropBox services. For conference calls we used Skype, instead of Google's Hangouts. The latter were found to be inconvenient, thus we chose Skype due to our familiarity with it and its simplicity. Within Skype, we made a group, which we used on the upfront determined dates - at least once a month, preferably twice. It was all a part of project management learning and students were fast in adopting and using it (Kolar \& Bubik, 2018).

\section{Survey}

The research on greening knowledge and awareness among general public was conducted using online survey. One hundred twelve people (from whole Slovenia) responded to 16 questions and this amount of data was processed statistically using Microsoft Office Excel and GraphPad Prism. The data was collected and stored through the Google Forms service. Next, the data was exported in the form of spreadsheets. From here, descriptive statistics, t-test analysis, regression analysis, and correlation analysis were conducted (Ladan, 2017; Bubik \& Kolar, 2018).

\section{Green pilot cases}

Within project activities students analyzed and constructed different examples of greening principles in various environments based on the literature study, survey analysis and environmental needs in exact environment, e.g. flat green roof in the city center of Velenje (Savinja statistical region, Slovenia), where Environmental Protection College is located (Ladan, 2017).

\section{Dissemination of results}

Different social media were used to disseminate, inform and spread the most important activities and main results (survey analysis and pilot cases presentation) to general public in both projects. Project web pages, Facebook, Twitter, Instagram and LinkedIn profiles were created with the aim to reach as big target group as possible. As Facebook connect various economic, social and cultural constituents and was the most active social networking tool during both projects, our analysis is based on it. We statistically measured the response, that we had encouraged with public posts and analyzed the site visitor dynamics during and after each project using Microsoft Office Excel and GraphPad Prism. Research results and conclusions were also published in various media for general and professional public (Ladan, 2017; Bubik \& Kolar, 2018; Kolar \& Bubik, 2018).

\section{RESULTS AND DISCUSSION}

\section{Survey about general knowledge on greening}

Out of all 112 respondents, the survey was filled by 43 men (38.4\%) and 69 women $(61.6 \%)$. The oldest respondent was 75 years, the youngest 17 
years old and the average age was 31 years. The standard deviation was 8.67 and median 30 .

Given the trends reported in (UN, 2017), we assumed the urban population rising trend, since more than $70 \%$ of respondents now live in urban areas. Due to better education conditions, employment opportunity and higher living quality in general, migration to urban centres is increasing. The results show that over half of the respondents $(55.3 \%)$ gained at least secondary school education, $63 \%$ of them obtained also bachelor's degree or even master's degree or doctorate (Ladan, 2017; Kolar \& Bubik, 2018).

Climate change and rapid urbanization have become two major issues related to human welfare and development around the world. Urbanization has taken place on all continents (except Antarctica) and is continuing, particularly in Asia and Sub-Saharan Africa (Guo et al., 2017). Together with the urban population elevation, there is also a growing need for new buildings, consequently causing a reduction of green areas. Therefore, an important goal of our survey was also to raise the awareness on greening among general population in Slovenia. The survey in general showed medium awareness of the interviewed population, as about $40 \%$ of respondents are (still) not aware of positive effects greening (e.g. green roofs) can have on the local climate (Ladan, 2017). Moreover, all the answers to the question about positive effects of green roofs were correct, but only $18.8 \%$ of respondents marked all the answers as an environmental advantage of greening (Table 1).

The most important barriers to increase greening are probably economical (the lack of financial resources and governmental financial supports), lack of awareness (the lack of environmental education), cultural (a non-environmental attitude) and urbanistic (the lack of space) (Bubik \& Kolar, 2018). The lack of environmental awareness is considered significant because people do not know how to be sustainable. This trend has also been demonstrated in a survey performed among higher education institutions in London, UK, where undertaking greening initiatives due to its benefit to the environment and ability to teach and demonstrate environmental stewardship, did not appear to be a driving force also within educated respondents. It was concluded that the barrier may be more due to a lack of knowledge, or misconceptions, and an institutional reluctance to change, than actual budgetary constraints (Dahle \& Neumayer, 2001).

Table 1: Awareness of general population on greening benefits in Slovenia

\begin{tabular}{|l|c|}
\hline \multicolumn{2}{|c|}{$\begin{array}{c}\text { Question: What are positive environmental } \\
\text { benefits of green roof? }\end{array}$} \\
\hline Decreased number of lung diseases & $8.7 \%$ \\
\hline Building energy savings & $11.9 \%$ \\
\hline Additional building isolation & $12.3 \%$ \\
\hline Increased biodiversity & $9.2 \%$ \\
\hline Noise reduction & $6.9 \%$ \\
\hline Stormwater management & $7.8 \%$ \\
\hline Air quality improvement & $16.6 \%$ \\
\hline Improved microclimate & $13.5 \%$ \\
\hline Urban heat island reduction & $13.2 \%$ \\
\hline
\end{tabular}

Awareness and knowledge of general population in Slovenia based on our survey is summarized in Figure 1. Majority of answer (63\%) regarding familiarity with the term "green roof" was positive and can be compared to other studies (Dahle \& Neumayer, 2001; Cortekar et al., 2016). In addition, respondents think that greening is an established practice in Slovenia and that green roofs are placed in our environment (68\%). However, less than a half of participants (38\%) have already seen them, among which only $41 \%$ seen them in Slovenia and the other $59 \%$ abroad. We find this result very interesting, especially as respondents think that greening is an established practice in Slovenia. In $94 \%$ they claimed they would support green building in their environment but would also expect a proper governmental financial support which coincides well with the study of Cortekar et al. (2016). 
A. Bubik and Raising awareness on environmental protection and improvement

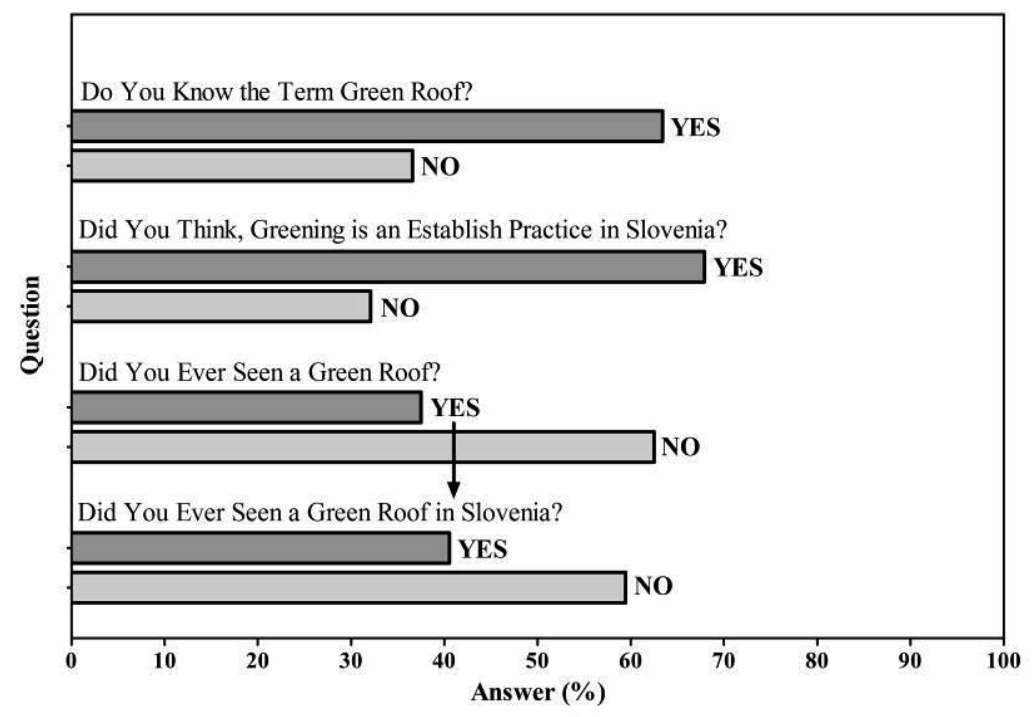

Figure 1: Awareness-raising knowledge of general population in Slovenia based on survey results.

\section{Greening practices within the projects - green pilot cases}

During both projects, students were encouraged to develop their own green ideas. They were very creative and developed various types of items using greening principles, which were innovative and easy for use. Within the project Gracilis, extensive flat green roof (Figure 2A), green curtains (Figure 2B), green box for ceiling decoration (Figure 2C) and wooden pots for indoor vegetable growing (Figure 2D) were designed (Kolar \& Bubik, 2018). In Convert project, flat green roof was predicted for aesthetics role, while green wall and green pots using climbing plants were predicted in order to soothe the smell of ecotoilet use and as a biological treatment plant.

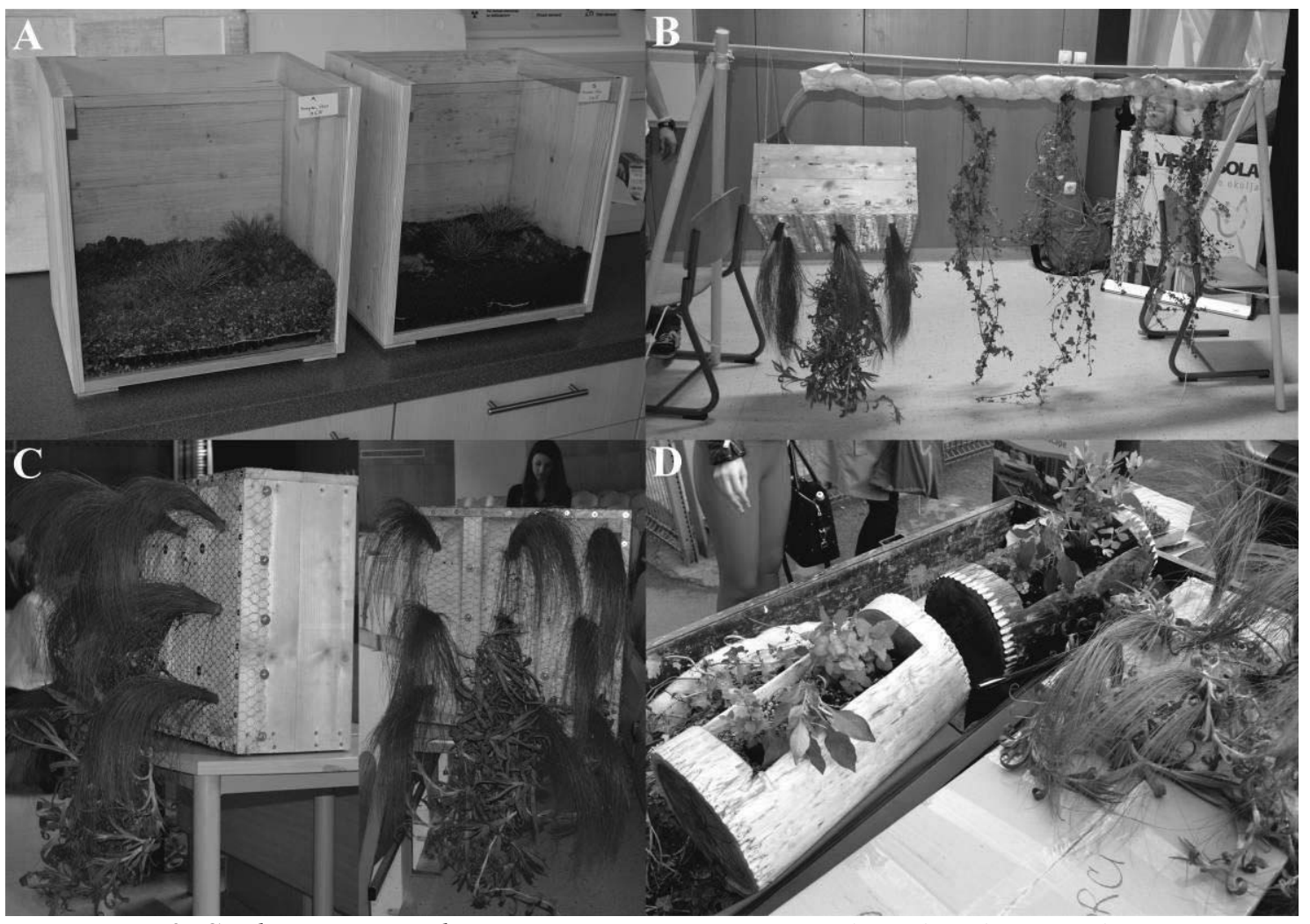

Figure 2: Student's green ideas as- awareness-raising tools within the Gracilis project. 


\section{Overview of organized public events}

As one of the main aims of both projects was raising public awareness, we organized several public events on various educational institutions (secondary schools, faculties), participated at various fairs (student's, business-trade on national or international level), scientific meetingsconferences with oral presentations and published papers in local newspapers and via e-news (Table 2 and 3 ).

Table 2: Listed awareness-raising public events within the projects Gracilis and Convert.

\begin{tabular}{|c|c|c|}
\hline Project & Public Event & No. of Guests \\
\hline \multirow{7}{*}{ GRACILIS } & Knowledge transfer event 1 & 35 \\
\hline & Knowledge transfer event 2 & 40 \\
\hline & Raising awareness among students at educational institutions & 150 \\
\hline & Project presentation at international, business and trade fair event & 100 \\
\hline & Project presentation at the student's fair event & 80 \\
\hline & $\begin{array}{l}\text { Final event of the project: Open round table in the frame of European } \\
\text { Sustainable Development Week }\end{array}$ & 75 \\
\hline & Scientific conference paper and paper presentation - Maribor, Slovenia & 30 \\
\hline Summary & 7 & 510 \\
\hline \multirow{4}{*}{ CONVERT } & Knowledge transfer event 1 & 30 \\
\hline & Knowledge transfer event 2 & 45 \\
\hline & $\begin{array}{l}\text { Final event of the project: Open round table in the frame of European } \\
\text { Sustainable Development Week }\end{array}$ & 90 \\
\hline & Scientific conference paper and paper presentation - Zrenjanin, Serbia & 50 \\
\hline Summary & 4 & 215 \\
\hline
\end{tabular}

What concerns project Gracilis we presented it at seven different events all performed in Slovenia, which reached around 510 people. Within Convert project, (events performed in Slovenia and one in Serbia) results were as follows - within four public events we reached a public of 215 people. As there were more events organized in the case of Gracilis, we can still say that results to Convert are comparable, taking into consideration Convert had four public events. Students in both cases showed best skills at the final event of the project, which was in both cases realized during the European Sustainable Week (31st May 5th of June). On that behalf, we created a short description of our both projects on the European map in the European Sustainable Week (www.esdw.eu) which was also an invitation to the final event of both projects (Table 2).

Table 3: Listed awareness-raising public published results within the projects Gracilis and Convert.

\begin{tabular}{|c|l|}
\hline Project & \multicolumn{1}{c|}{ Dissemination of "written, published" results } \\
\hline \multirow{5}{*}{ GRACILIS } & $\begin{array}{l}\text { Publication of two professional news in the EOL expert magazine, a specialized magazine for } \\
\text { sustainable development in Slovenia }\end{array}$ \\
\cline { 2 - 3 } & A professional article in the magazine "Delo in dom" \\
\cline { 2 - 3 } & Two short articles in the local newspaper "Naščas" \\
\cline { 2 - 3 } On-line news on the portal celje.info \\
\cline { 2 - 3 } & $\begin{array}{l}\text { A report of the final project event in the monthly information bulletin "Obveščevalo" of } \\
\text { Environmental Protection College }\end{array}$ \\
\cline { 2 - 3 } & On-line news on www.esdw.eu - European Sustainable Development Week \\
\hline & $\begin{array}{l}\text { Publication of professional news in the EOL expert magazine, a specialized magazine for } \\
\text { sustainable development in Slovenia }\end{array}$ \\
\cline { 2 - 3 } & Publication of a professional article in the EOL expert magazine \\
\cline { 2 - 3 } & $\begin{array}{l}\text { A report of the final project event in the monthly information bulletin "Obveščevalo" of } \\
\text { Environmental Protection College }\end{array}$ \\
\cline { 2 - 3 } & On-line news on www.esdw.eu - European Sustainable Development Week \\
\hline
\end{tabular}

Students and mentors were trying to share the results and the experiences on projects also through written activity. The most important achievements were: publications in national magazine "Embalaža, Okolje in Logistika" (EOL), national professional magazine "Delo in Dom", presentation of some results in the faculty 
information bulletin and a final project elaborate (Table 3).

\section{Dissemination through the social networks - Facebook case with statistical analysis and web page characteristics}

Facebook profiles were established at the beginning of each project and first posts were created cca 1 month after project meetings. Gracilis profile (@ProjektGracilis) gained all together 66 and Convert profile (@zelenastranisca) 61 followers during the project.

Since Facebook (FB) was the most commonly used social profile during both projects, we performed the quantitative analysis of their contents and activities for two periods; at the time each project was carried out (5-months periods) and during the first 4 months after each project has ended. The analysis showed that the number of visitors during the Gracilis project was around 6500, and afterwards around 2800, what is $65 \%$ less compared to the time, when project was active. In the case of the Convert project, we detected smaller number of visitors compared to Gracilis; 4300 visitors during and 190 after the project (95 $\%$ reduction in visitors' number). In average, during the Gracilis project, the FB site was visited 57-times daily (Figures 3A) and 23-times in 4- months period after the project (Figures 3C). The highest detected number of guests was 588 during the project and 966 after project. Surprisingly, the greatest effect was achieved with our activities after the project. More precisely, at the time, the project was ranked as one of the best student projects of the year 2017 and we participated in the competition titled "Best Project 2017" (Figures 3A and C). Adversely, the Convert project had reached a maximum response during the project; that is 1299 of visitors at the time we organized the final project event with a round table (Figures 3B). An average daily visit during the project was 40 and afterwards only 2 (Figures 3B and D). The day with the largest response after the end of the project contained 28 insights and was correlated with the posting of the new and the only information from the 4-months period after the project (Figure 3D).

Both cases show, how important is to obtain a constant group of followers, which also increase with regular activities, like sharing news and results through a new post. If there are no posts, the actuality and promotion of the FB page is extremely low. This trend was seen after both projects, but especially in case of Gracilis, where no followers visited the FB page, if there were no new posts (Figure 3B).
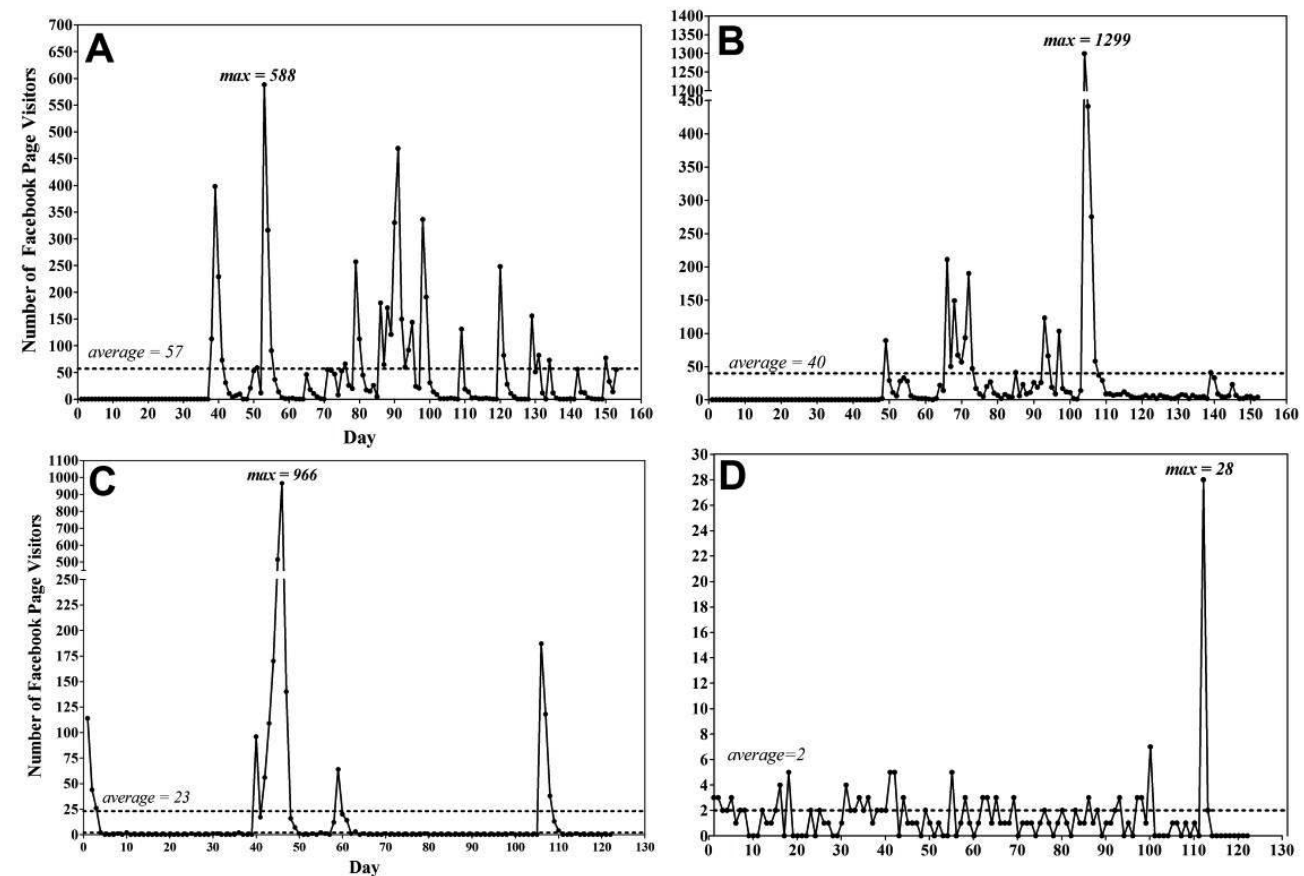

Figure 3: Daily visits of Facebook pages during the 5-months period of projects (A for Gracilis, $B$ for Convert) and in a 4-months period after the project has been ended ( $C$ for Gracilis, $D$ for Convert). 
In both projects, activities and results were promoted through different types of FB publications; photos, videos, sharing important links, as well as describing the status of the project. The Gracilis project, where the primary aim was raising awareness on greening, generated 55 publications in the 5-month period of the project, and Convert 36, each gaining 1117 and 716 responses from visitors, respectively (Table 4). The awareness-raising activities were mostly published through posting a photograph and short news (more than $50 \%$ of all publications) in both projects. The difference between the projects was that in the Convert project, we upgraded publishing with videos and self-assembly short films (Table 4).
In the analyzed 4-months period after project has ended, we obtained significant differences between the projects. After the Gracilis project, another 12 FB activities (posting 8 photos and 4 links) were created, while after the Convert project, only one was published (data not shown). As a result, there were several more active FB guests after the Gracilis project, where 146 guest activities were recorded in comparison to only 4 after the Convert project. Differences are attributed also to the nature of the projects, since Gracilis was more dedicated to raising awareness of the wider general public, and the fact, that Gracilis project was ranked as one of the best student projects in Slovenia.

Table 4: Analysis of post types and page guest activities during the projects.

\begin{tabular}{|c|c|c|c|c|c|c|c|c|c|c|}
\hline \multirow{2}{*}{$\begin{array}{c}\text { Type of } \\
\text { Post }\end{array}$} & \multicolumn{2}{|c|}{ PHOTO } & \multicolumn{2}{|c|}{ VIDEO } & \multicolumn{2}{|c|}{ LINK } & \multicolumn{2}{|c|}{ STATUS } & \multicolumn{2}{|c|}{ ALL } \\
\hline & Gracilis & Convert & Gracilis & Convert & Gracilis & Convert & Gracilis & Convert & Gracilis & Convert \\
\hline \multirow{2}{*}{$\begin{array}{c}\text { Number } \\
\%\end{array}$} & 35 & 18 & $\mathbf{0}$ & 4 & 16 & 11 & 4 & 3 & \multirow{2}{*}{55} & \multirow{2}{*}{36} \\
\hline & $63.6 \%$ & $50.0 \%$ & - & $11.1 \%$ & $29.1 \%$ & $30.6 \%$ & $7.3 \%$ & $8.3 \%$ & & \\
\hline \multirow{2}{*}{ like } & 204 & 131 & - & $\overline{77}$ & 1117 & 31 & - & - & \multirow{2}{*}{321} & \multirow{2}{*}{169} \\
\hline & $63.6 \%$ & $77.5 \%$ & - & $4.1 \%$ & $36.4 \%$ & $18.3 \%$ & - & - & & \\
\hline \multirow[b]{2}{*}{ share } & 8 & 18 & - & - & 8 & 3 & - & - & \multirow{2}{*}{16} & \multirow{2}{*}{21} \\
\hline & $50.0 \%$ & $85.7 \%$ & - & - & $50.0 \%$ & $14.3 \%$ & - & - & & \\
\hline \multirow{2}{*}{ comment } & - & 2 & - & - & 5 & - & - & - & \multirow{2}{*}{5} & \multirow{2}{*}{2} \\
\hline & - & $100 \%$ & - & - & $100 \%$ & - & - & - & & \\
\hline \multirow{2}{*}{ photo view } & 480 & 274 & - & - & - & - & - & - & \multirow[b]{2}{*}{480} & \multirow{2}{*}{274} \\
\hline & $100 \%$ & $100 \%$ & - & - & - & - & - & - & & \\
\hline \multirow{2}{*}{$\begin{array}{l}\begin{array}{l}\text { other } \\
\text { clicks }\end{array} \\
\end{array}$} & 159 & 145 & - & 25 & 78 & 27 & - & 1 & \multirow{2}{*}{237} & \multirow{2}{*}{198} \\
\hline & $67.1 \%$ & $73.2 \%$ & - & $12.6 \%$ & $32.9 \%$ & $13.6 \%$ & - & $0.5 \%$ & & \\
\hline \multirow{2}{*}{ link clicks } & 5 & - & - & - & 53 & 26 & - & 1 & \multirow[b]{2}{*}{58} & \multirow{2}{*}{27} \\
\hline & $8.6 \%$ & - & - & - & $91.4 \%$ & $96.3 \%$ & - & $3.7 \%$ & & \\
\hline \multirow{2}{*}{ video play } & - & - & - & 25 & - & - & - & - & \multirow{2}{*}{$\mathbf{0}$} & \multirow{2}{*}{5} \\
\hline & - & - & - & $100 \%$ & - & - & - & - & & \\
\hline & & & & MBER & ALL F & GE GU & EST AC & IVITIES & 1117 & 716 \\
\hline
\end{tabular}

At the end of the projects, we were interested in how many random and/or regular visitors of FB pages we have gained with our activities (summarized in Table 5). As expected, most people visited the page 1-2-times, regular followers at the time of the project (who visited the site more than 21 times) were 13 in the case of Gracilis and 18 in the case of Convert project. In 4months period after projects ended, access to the FB page was approximately $60 \%$ lower in Gracilis case and even $90 \%$ in Convert case, compared to 5-months period projects were carried out. According to the total number of page views during both projects (6577 for Gracilis and for 4241 Convert) we considered, that we achieved a large target group, which is not defined as a final number, since many followers were also acquired through other social media in events. There are lots of benefits from the collaborative, distributed approaches promoted by sincere use of social networking sites, (such as FB in our case) but there are information security and privacy concerns, which we should always keep in mind while using it (Dushyant et al., 2014).

Both projects also had their own websites named: www.gracilis.si and www.zelenastranisca. com. They were created with the purpose of presenting the content of the projects more in depth, to present people who took the active role in both projects and mostly as a media for information sharing. Students also wrote their blogs there and gallery was created as well as all the public events were published there, too. 
Table 5: Analysis of page accesses and their frequency during the projects.

\begin{tabular}{|c|c|c|c|c|}
\hline & \multicolumn{2}{|c|}{ GRACILIS } & \multicolumn{2}{c|}{ CONVERT } \\
\hline & During the Project & After the Project & During the Project & After the Project \\
\hline Period in Days & 153 & 122 & 152 & 121 \\
\hline \hline Frequency & \multicolumn{5}{|c|}{ Number of Page Accesses } \\
\hline 1 & 4015 & 1449 & 2995 & 127 \\
\hline 2 & 1306 & 688 & 704 & 40 \\
\hline 3 & 551 & 417 & 226 & 5 \\
\hline 4 & 311 & 84 & 97 & 7 \\
\hline 5 & 140 & 37 & 60 & 3 \\
\hline $6-10$ & 206 & 91 & 96 & 3 \\
\hline $11-20$ & 35 & 3 & 45 & no data \\
\hline $21+$ & 13 & 1 & 18 & 2 \\
\hline
\end{tabular}

\section{Development of good communication and networking skills}

As communication is the most important skill either in personal life or in business, project management learning included also an insight into communication skills development. Effective communication abilities are fundamental to success in many aspects of life. Many jobs require them and people with good communication skills usually enjoy better interpersonal relationships with friends and family. Effective communication is a key interpersonal skill and learning how we can improve our communication has many benefits. Communi-cation is therefore a two-way process, so improving communication involves both - how we send and how we receive messages. We showed students how to listen each other, how they encourage, maintain positivity, reduce stress and mostly how they communicate effectively, so with communicating clearly, they can help avoid misunderstandings and potential conflict with others. The messages should always be clearly understood. What concerns networking, students were quite skilled at it and they had plenty ideas how and where projects could be presented or, to which partners we could connect in the future or they have already contact them on their own. They have, however, built their own network connected to the project or strengthened the existing one. In the future, all obtained skills provide students and mentors with an approach towards dealing with environmental problems and especially the idea how to successfully raise awareness of general public about it. Based on the creativity in responsibility they showed through both projects, students will become more motivated to get involved in entrepreneurial processes. Such projects could establish an adequate environment for supporting young entrepreneurship, which is often very poor, or even inexistent among young population (Ćoćkalo et al., 2017).

\section{CONCLUSIONS}

Within both projects we established several different approaches to create an environment or better, a combination of tools best serving in raising public awareness. First, we performed a simple survey to see how the general knowledge is connected to the three terms: greening, green roof, green wall in case of Gracilis project. Results had shown a lack of knowledge and experiences with greening principles among general public in Slovenia. Therefore, we started to organize different public events, produce several professional or scientific articles with public presentations and address the general public through social media, especially Facebook profiles. Based on our project experiences, one of the most important measures that needs to be undertaken to overcome barriers to greening in Slovenia in the future is to raise the environmental awareness within local communities and wider. We showed that environment protection and improvement can be made also trough students project with low costs and using innovative and cooperative approach.

Communication skills and networking development were positive attributes to both projects, several students showed a great promotion especially at presenting their results or explaining basic principles to interested public. All these we found as an added value to both projects and a solid example how knowledge acceptance results in excellent knowledge sharing - e.g. raising aware-ness. 
There is still some room for improvement of described and used tools in both projects, but now we have a basic ground on how to approach, analyze and promote public awareness, change views and attitudes towards certain topic and achieve the goal of sustainable development of greening awareness in public action. We will try to transfer the gained results and experience to the next level where green products will be developed more in depth and a possible civil initiative having a public e-forum will be formed in Slovenia to continue work on green awareness.

Perhaps we can conclude with a thought from an opinion published on EIT - Climate KIC platforma: According to the internationally recognized biologist and author, Edward $\mathrm{O}$. Wilson, human beings have an inherent emotional bond with all living organisms, so they seek connections with nature, which he calls biophilia, the "love of life or living systems". European cities (Birmingham in the UK and Vitoria Gasteiz in Spain) are already part of the international network of Biophilic Cities - implementing described philosophy in practice. We found this as a role model and hopefully such examples will thrive in the Slovenian environment soon.

\section{ACKNOWLEDGEMENT}

First and foremost, we would like to thank our student, Franciska Ladan, who did an enormous and excellent work, collected in her thesis and also cited in this paper. We also thank Dr. Daniel Vladušič for participation in project GRACILIS and providing us with an excellent English proofreading. The pilot study regarding green roofs was a part of the European project Climate KIC, programme Pioneers into Practice, within the group assignment entitled "Greening of buildings". GRACiLIS - Green AnswerS project CLImate Change - Greening in response to climate change and CONVERT (Carbon negative External Toilets) were co-financed by the Ministry of Education, Science and Sport of the Republic of Slovenia, The Public Scholarship, Development, Disability and Maintenance Fund of the Republic of Slovenia and European Social Fund from the project calls "The Creative Paths to Knowledge".

\section{REFERENCES}

Alexandria, E. \& Jones, P. (2008). Temperature decreases in an urban canyon due to green walls and green roofs in diverse climates. Building and Environment, 43, 480-493.

Bubik, A. \& Kolar, L. (2018). Greening as a perspective solution for urban microclimate mitigation - a pilot study. Proceedings of the VIII International Conference "Industrial Engineering and Environmental Protection 11-12th October 2018", Zrenjanin, Serbia.

Cortekar, J., Bender, S., Brune, M., Groth, M. (2016). Why climate change adaptation in cities needs customised and flexible climate services. Climate Services, 4, 42-51.

Ćoćkalo, D., Đorđević, D., Nikolić, M., Stanisavljev, S., Terek, E. (2017). Analysis of possibilities for Improving Entrepreneurial Behaviour of Young People - Research Results in Central Banat District. Journal of Engineering Management and Competitiveness, 7(2), 97-108.

Dahle, M. \& Neumayer, E. (2001). Overcoming barriers to campus greening: a survey among higher educational institutions in London, UK. International Journal of Sustainability in Higher Education, 2(2), 139-160.

Dushyant, T., Zenit, R., Dhwani, R. (2014) Social Media and Public Awareness. International Journal of Software and Hardware Research in Engineering, 2(7), 60-65.

EIT - Climate KIC: How can we make cities climate and human-friendly? Lehoczky A. of the Centre for Climate Change, URV. http: https://www.climatekic.org/opinion/make-cities-climate-human-friendly/

Guo, X., Jørgensen, G., Vejre, H. (2017). How can urban green spaces be planned for climate adaptation in subtropical cities? Ecological Indicators, 82, 152162.

Kolar, L. \& Bubik, A. (2018). Best practices in environmental protection through education and information activities: The GRACILIS showcase. Proceedings of the VIII International Conference "Industrial Engineering and Environmental Protection 11-12th October 2018”, Zrenjanin, Serbia.

Ladan, F. (2017). Green roofs - analysis of a pilot case and research for potential location in the municipality of Velenje. Bachelor Thesis, 1-48. Environmental Protection College, Velenje, Slovenia.

Lutz, W. (2017). How population growth relates to climate change. Proceedings of the National Academy of Sciences of the United States of America, 114 (46), 12103-12105; published ahead of print November 1, 2017.

Panacek, E.A. (2008). Survey-based research: General principles. Air Medical Journal, 27(1), 14-16. 
Stephenson, J. Newman, K., Mayhew, S. (2010). Population dynamics and climate change: what are the links? Journal of Public Health, 32(2), 150-156.

United Nations (2017). World Population Prospects: The 2017 Revision (Department of Economic and Social Affairs, Population Division, New York). Available at https://esa.un.org/unpd/wpp/. Accessed October 12, 2018.
Voytek, B. (2017). Social Media, Open Science and Data Science Are Inextricably Linked. Neuron, 96(6), 1219-1222.

Whitford, V., Ennos, A.R., \& Handley, J.F. (2001). "City form and natural process" - indicators for the ecological performance of urban areas and their application to Merseyside, UK. Landscape and Urban Planning, 57, 91-103.

\section{PODIZANJE SVESTI O ZAŠTITI ŽIVOTNE SREDINE I POBOLJŠANJA KROZ STUDENTSKE PROJEKTE: STUDIJA SLUČAJA}

Podizanje svesti o određenoj temi ili problemu vrlo je razrađeno širenjem elektronskih medija, a time i brzom dostavom informacija. Iskustvo pokazuje da je ovo najbolji i najuverljiviji način edukacije javnosti. U okviru ovog rada pokazali smo kako dva studentska projekta, koja koriste različite aktivnosti, podižu svest javnosti. Takođe, predstavljamo pozitivne i negativne efekte kampanja i kako se oni mogu povezati zajedno u zanimljiv i poučni realni scenario. Poznavanje javnosti o ozelenjavanju i njenim koristima, koje se odnose na klimatske promene, proučavane su u Sloveniji, s naglaskom na Savinjsku statističku regiju. Koristili smo istraživanja, pilot slučajeve, organizovane javne događaje i alate za saradnju na daljinu u okviru ove studije. Primetili smo manjak znanja i iskustva u generalnoj populaciji sa principima ozelenjavanja. Međutim, dobre komunikacione sposobnosti, umrežavanje i privlačna održiva rešenja su dovela do povećanja svesti o ozelenjavanju. Naša studija slučaja daje primere o mogućim pris tupima u okviru prevencije klimatskih promena i podstiče buduće studentske projekte. Mi smo saželi rešenja i razvili odgovarajuće alate koji se mogu implementirati u efektnijem i efikasnijem podizanju svesti o integralnom održivom razvoju i ozelenjavanju.

Ključne reči: Studentski projekti, Svesnost, Ozelenjavanje, Istraživanje, E-alati, Održivi razvoj. 